\title{
Incidences of Calf Diarrhea and the Associated Risk Factors in Ivory Coast (2015-2017)
}

\author{
Ocorrências de Diarréia de bezerro e os Fatores de Risco Associados na Costa do Marfim (2015- \\ 2017)
}

\author{
Jacques Danho Monney ${ }^{1 \star}$, Edgard Valery Adjogoua ${ }^{2}$, Yahaya Karamoko ${ }^{1},{\text { Agbaya } \text { Akran }^{2}}^{2}$ \\ ${ }^{1}$ Nangui Abrogoua University, Abidjan, Côte d'Ivoire. * Author for correspondence: monneyjacques@yahoo.fr \\ ${ }^{2}$ Pasteur Institute, Abidjan, Côte d'Ivoire.
}

Submission: 05/03/2020 / Acceptance: 05/08/2020

\begin{abstract}
Diarrhea is the most important disease of neonatal calves, and it results in the greatest economic losses. A longitudinal observational study was conducted from September 2015 to October 2017. This study proposes to investigate the incidence of diarrhea in calves and their mortality rate so as to identify potential risk factors related to the occurrence of calf diarrhea on 372 farms in the regions of Abidjan, Bouake, Bondoukou, and Korhogo in Ivory Coast. Information on potential risk factors was collected based on personal observations from regular visits to the farms and from a survey conducted during the period of the study. A total of 2020 calves under the age of three months were selected. Only 347 (17.17\%) of the 2020 calves showed signs of diarrhea. The overall mortality rate was $0.39 \%$. Based on the survey, colostrum feeding, the calf's age and sex, calf housing, seasonal variation, the calving period, environment conditions, the ignorance of herdsmen, and management systems were found to be the major risk factors for gastroenteritis in calves. Calves reared in an extensive system were less susceptible to neonatal diarrhea. The calf health and management issues found in this study can be resolved by creating awareness among farm owners and implementing better calf management practices and cattle vaccination programs.
\end{abstract}

KEYWORDS: diarrhea, calf, mortality, risk factors, Ivory Coast.

\section{RESUMO}

O presente estudo tenta investigar a incidência de diarréia na taxa de mortalidade de bezerros, determinando potenciais fatores de risco associados à ocorrência de diarréia em 372 fazendas das regiões de Abidjan, Bouake, Bondoukou e Korhogo na Costa do Marfim. As informações sobre os possíveis fatores de risco foram coletadas por observação pessoal durante a visita regular às fazendas e a partir de questionário realizado durante o período do estudo. Foram selecionados um total de 2020 bezerros com até três meses de idade. Dos 2020 bezerros pesquisados, apenas $347(17,17 \%)$ apresentaram sinais de diarréia. A taxa de mortalidade geral foi de $0,39 \%$. Com base na pesquisa do questionário, a alimentação com colostro, idade e sexo do bezerro, alojamento do bezerro, estações, período de parto, ambiente, ignorância dos pequenos proprietários e sistema de gestão também foram os principais fatores de risco considerados significativos para promover a gastroenterite do bezerro. Os bezerros criados em um sistema extenso eram menos suscetíveis à diarréia neonatal. Os problemas de saúde e manejo de bezerros encontrados neste estudo podem ser resolvidos com a conscientização dos proprietários das fazendas e a implementação de práticas aprimoradas de manejo de bezerros e vacinação de vacas.

PALAVRAS-CHAVE: diarréia, bezerro, mortalidade, fatores de risco, Costa do Marfim.

\section{INTRODUCTION}

Gastrointestinal disease is one of the most common causes of illness, morbidity, and mortality among newborn calves in the world (RAVARY et al. 2006, MAES et al. 2010). Calves are at the greatest risk of developing diarrhea during the first week of life. Diarrheic, unhealthy calves are an important source of economic loss for the farmer (ØSTERAS et al. 2007).

Management of sick animals becomes an additional burden for farmers. The reported incidences of 
diarrhea varied noticeably among herds throughout the world (between 10\% and 70\%) (WUDU et al. 2008, ASEFA \& ASHENAFI 2016). The reported mortality rates varied between $1.5 \%$ and $50 \%$ (MELLADO et al. 2014, DAGNE et al. 2018). Losses have been as high as 50\% for the calf crop because of poor management (THICKET et al. 2003). It is not only a loss of the calf's present value; it is also a loss in genetic potential for herd improvement (ABEBAW et al. 2018).

Each farm's performance level depends on many factors that interact with each other. The main risk factors for calf diarrhea are grouped into two categories: noninfectious and infectious causes. The important infectious viral agents include bovine group A Rotavirus, bovine coronavirus, and bovine viral diarrhea virus. Bacterial causes such as Salmonella spp., Escherichia coli (E. coli) $\mathrm{K99} 9_{+}$, and Clostridium perfringens (C. perfringens) type $C$ and protozoa such as Cryptosporidium parvum (C. parvum) and coccidiosis, either alone or in combination, affect young calves (ACHA et al. 2004, ABEBE et al. 2008). Some of the noninfectious causes include management problems, inadequate nutrition, exposure to severe environment conditions, insufficient attention to the newborn calf, and failure of passive transfer of immunity.

Currently, very few studies have observed diarrhea in newborn calves from tropical areas. However, adequate studies on calf management and its impact on calf health have not been conducted in Ivory Coast. Hence, the purpose of this study was to describe the incidence of calf diarrhea and evaluate the risk factors related to calf diarrhea on farms through an ecopathological approach.

\section{MATERIAL AND METHODS}

\section{Area of field research}

The study was conducted with randomly selected herds of cattle in Abidjan, Bouake, Bondoukou, and Korhogo from September 2015 to October 2017. Abidjan is located in the south of Ivory Coast, and its geographical coordinates are $5^{\circ} 19^{\prime} 0.001^{\prime \prime} \mathrm{N}, 4^{\circ} 1^{\prime} 59.999^{\prime \prime} \mathrm{W}$. Bouake is located in the central part of the country, and it geographical coordinates are $7^{\circ} 40^{\prime} 59.999 " \mathrm{~N}, 5^{\circ} 1^{\prime} 0.001{ }^{\prime \prime} \mathrm{W}$. Korhogo is located in the north of Ivory Coast, and Bondoukou is in the northeast. Their respective geographical coordinates are $9^{\circ} 25^{\prime}$ $0.001^{\prime \prime} \mathrm{N}, 5^{\circ} 37^{\prime} 0.001^{\prime \prime} \mathrm{W}$ and $8^{\circ} 2^{\prime} 52.379 " \mathrm{~N}, 2^{\circ} 48^{\prime} 28.311^{\prime \prime} \mathrm{W}$.

Four seasons are observed in the southern and central regions (Abidjan and Bouake): two rainy seasons and two dry seasons. In the north (Bondoukou and Korhogo), there are two seasons: a dry season and a rainy season.

\section{Target population and farm selection}

Only diarrheic calves under the age of three months were observed during the period of the investigation. A random number sampling algorithm was used to identify the herd for enrollment in the study. The enumeration rule was that if a farm was selected, then all the calves were enrolled in the study. Only mortality due to neonatal diarrhea was taken into account and calves with diarrhea from other known causes were excluded from the study population.

\section{Data collection}

This longitudinal prospective study made use of a structured questionnaire on the farms' calf rearing practices that might have caused diarrhea in the calves. A survey containing various questions focused on critical factors that might be associated with calf diarrhea was made of the selected cattle farms. The questionnaire was divided into seven groups of management practices that may affect calf health: farm characteristics, health, population, feeding, housing, management techniques, and environment conditions. On the visits, the survey questions were completed during an interview with the farm manager in order to identify management practices and data on all the calves. The calves were paid a visit once every ten days up until the end of the investigation periods (up to three months). There were also emergency visits whenever there were calls from farms due to calf health problems.

\section{Data analysis}

$$
\begin{aligned}
& \text { Incidence }(\%)=\frac{\text { number of new cases }}{\text { total population of calvas }} \times 100 \\
& \text { Mortality }(\%)=\frac{\text { number of daad }}{\text { total population of calves }} \times 100
\end{aligned}
$$

Data obtained from the field was processed with the software $\mathrm{R}$ version 2.12.1. The chi-squared test was used to determine the statistical significance of the proportions of the various study parameters. For all of the analyses, the significance level was set to $p \leq 0.05$.

\section{RESULTS}




\section{Farm Characteristics}

From a total of 372 farms, 152 herds from the regions of Korhogo and Bondoukou, 81 from Bouake, and 108 from Abidjan were randomly selected. These are regions of Ivory Coast with a high concentration of cattle farming.

These farms follow an extensive mixed production system (beef and dairy). The animals were allowed to graze on most of the farms, and their feed was supplemented with concentrates. There was no housing for the animals on $354(95.16 \%)$ of the 372 farms surveyed; they were reared on muddy grounds and weatherexposed parks. In the early morning, the calves were gathered in a part of the park while the entire herd went in search of fodder. The calves did not join their mothers until dusk.

Most of the respondents were male (98.5\%). The herdsmen who were engaged in these activities were Fulani from Mali, Burkina Faso, and Guinea. As for the herdsmen's literacy rate, $90 \%$ were illiterate.

\section{Herd proportions affected by calf diarrhea}

The results of this study revealed that 301 of the 341 herds were affected by calf diarrhea during the period of the study, which represented $88.10 \%$ (Table 1 ).

Table 1. Proportion of farms from three regions affected by calf diarrhea during the period of the study.

\begin{tabular}{lccc}
\hline Regions & Surveyed farms & $\begin{array}{c}\text { Farms affected by } \\
\text { diarrhea }\end{array}$ & $\begin{array}{c}\text { Proportion of farms } \\
\text { affected by diarrhea (\%) }\end{array}$ \\
\hline Abidjan & 102 & 92 & 90.2 \\
Bouake & 98 & 83 & 84.7 \\
Bondoukou and Korhogo & 141 & 126 & 89.4 \\
\hline Total & 341 & 301 & 88.1 \\
\hline
\end{tabular}

\section{Incidence of calf diarrhea}

The major calf health problem reported in this study was calf diarrhea. This study focused on a total population of 2020 calves, and 347 calves showed signs of diarrhea (Table 2). The occurrence of diarrhea varied noticeably among the herds. The incidence of calf diarrhea was higher in Abidjan, at a rate of $20.40 \%$, followed by Korhogo and Bondoukou, with an incidence rate of $16.09 \%$. Bouake appeared to be least affected by diarrhea, with an incidence rate of $12.51 \%$. The incidence rate of diarrhea in newborn calves in Ivory Coast was in the order of $17.17 \%$.

Table 2. Distribution of incidence and dehydration rate related to various parameters during survey.

\begin{tabular}{|c|c|c|c|c|c|c|}
\hline Parameters & & $E$ & $\mathrm{DC}$ & IDD (\%) & $\mathrm{DC}$ & DR (\%) \\
\hline \multirow[b]{2}{*}{ Sex } & $\mathrm{M}$ & 1019 & 213 & $61.38^{\mathrm{a}}$ & 80 & 23 \\
\hline & $\mathrm{F}$ & 1001 & 134 & $38.62^{\mathrm{b}}$ & 52 & 15 \\
\hline \multirow[b]{2}{*}{ Herd size } & size $\leq 20$ & 825 & 95 & $27.37^{\mathrm{a}}$ & 31 & 23.48 \\
\hline & size $>20$ & 1195 & 252 & $72.62^{b}$ & 101 & 76.50 \\
\hline \multirow{3}{*}{ Age } & 1 month & 1276 & 219 & $63.15^{\mathrm{a}}$ & 84 & 24.2 \\
\hline & 2 months & 580 & 99 & $28.70^{b}$ & 36 & 10.4 \\
\hline & 3 months & 164 & 29 & $8.15^{\mathrm{c}}$ & 12 & 3.4 \\
\hline \multirow[b]{2}{*}{ Seasons } & Dry $\quad$ Season & 787 & 101 & $29.39^{\mathrm{a}}$ & 47 & 13.5 \\
\hline & rainy Season & 1233 & 246 & $70.60^{b}$ & 85 & 24.5 \\
\hline \multirow[b]{2}{*}{ Calving } & Rest period & 683 & 105 & $30.25^{a}$ & 31 & 8.9 \\
\hline & Calving period & 1337 & 242 & $69.74^{\mathrm{b}}$ & 101 & 29.1 \\
\hline \multirow[b]{3}{*}{ Regions } & Abidjan & 701 & 152 & $21.68^{b}$ & 62 & 17.8 \\
\hline & Bouake & 510 & 67 & $13.13^{\mathrm{a}}$ & 19 & 5.47 \\
\hline & $\begin{array}{l}\text { Bondoukou and } \\
\text { Korhogo }\end{array}$ & 809 & 128 & $15.28^{\mathrm{a}}$ & 51 & 14.6 \\
\hline Parameters & & $E$ & $\mathrm{DC}$ & IDD (\%) & $\mathrm{DC}$ & DR (\%) \\
\hline \multirow[b]{2}{*}{ Sex } & $\mathrm{M}$ & 1019 & 213 & $61.38^{\mathrm{a}}$ & 80 & 23 \\
\hline & $\mathrm{F}$ & 1001 & 134 & $38.62^{b}$ & 52 & 15 \\
\hline \multirow[b]{2}{*}{ Herd size } & size $\leq 20$ & 825 & 95 & $27.37^{\mathrm{a}}$ & 31 & 23.48 \\
\hline & size $>20$ & 1195 & 252 & $72.62^{b}$ & 101 & 76.50 \\
\hline \multirow{3}{*}{ Age } & 1 month & 1276 & 219 & $63.15^{\mathrm{a}}$ & 84 & 24.2 \\
\hline & 2 months & 580 & 99 & $28.70^{b}$ & 36 & 10.4 \\
\hline & 3 months & 164 & 29 & $8.15^{c}$ & 12 & 3.4 \\
\hline \multirow[b]{2}{*}{ Seasons } & Dry Season & 787 & 101 & $29.39^{a}$ & 47 & 13.5 \\
\hline & rainy Season & 1233 & 246 & $70.60^{b}$ & 85 & 24.5 \\
\hline
\end{tabular}


Continuation Table 2...

\begin{tabular}{clrrrrr}
\hline \multirow{3}{*}{ Calving } & Rest period & 683 & 105 & $30.25^{\mathrm{a}}$ & 31 & 8.9 \\
\cline { 2 - 7 } Regions & Calving period & 1337 & 242 & $69.74^{\mathrm{b}}$ & 101 & 29.1 \\
\hline \multirow{3}{*}{ Abidjan } & 701 & 152 & $21.68^{\mathrm{b}}$ & 62 & 17.8 \\
\cline { 2 - 7 } & Bouake & 510 & 67 & $13.13^{\mathrm{a}}$ & 19 & 5.47 \\
\cline { 2 - 7 } & $\begin{array}{l}\text { Bondoukou and } \\
\text { Korhogo }\end{array}$ & 809 & 128 & $15.28^{\mathrm{a}}$ & 51 & 14.6 \\
\hline
\end{tabular}

$\mathrm{E}=$ Total calf population, $\mathrm{DC}=$ Diarrheal Calf, IDD $=$ Incidence of diarrhea, $\mathrm{DC}=$ Number of Dehydrated Calf, DR $=$ Dehydration Rate. Percentage with different superscripts letters ( $a, b, c, d)$ within the same column and class are statistically different.

\section{Age and sex of calves}

Most of the cases of diarrhea occurred during the first month of life (Table 2). There was an incidence rate of $63.15 \%$ in the first month after birth, and $28.7 \%$ of the calves manifested diarrhea during the second month of life. The occurrence of diarrhea declined in the third month $(8.15 \%)$. The proportional difference between the different age groups was statistically significant $(p=0.049<0.05)$. The age of the calves had a significant association with the occurrence of diarrhea.

Variation in susceptibility to calf diarrhea related to the calf's sex revealed that male calves had a higher susceptibility, with 213 out of 347 (61.38\%), than female calves, with 134 out of 347 (38.62\%) (Table 2). Male calves were more prone to death than their female counterparts. The difference between the proportions of males and females was statistically significant $(p=0.049<0.05)$. The sex of the calves had a significant association with the occurrence of diarrhea.

\section{Seasonal variation}

The seasons have a significant effect on the occurrence of diarrhea (Table 2). The seasonal variation of the incidence rate was also considerable, with a higher rate of incidence during the rainy season (May, June, July, August, September, and October). In general, the incidence rate of calf diarrhea was higher in the rainy season than in the dry season (November, December, January, February, and March).

The difference between the proportions of sick calves in the rainy and dry seasons was statistically significant $(p=0.006<0.05)$. Seasonal variation had a significant association with the occurrence of diarrhea.

\section{Calving season}

Most of the cases of diarrhea occurred during calving season $(70 \%)$. This period favored the occurrence of diarrhea (Table 2). The difference between the proportions of diarrheic calves in the calving periods was statistically significant $(p=0.025<0.05)$. Calving season had a significant association with the occurrence of diarrhea.

\section{Zootechnical implications}

There were recorded cases (95\%) of severe dehydration, morbidity, and weight loss of diarrheic calves on many of the farms surveyed. These cases were associated with the weight loss expected after the calves are weaned and the stunted development that strongly influences the herd's zootechnical performance.

\section{Incidence of mortality}

The mortality rate was considerably lower on the farms. There was a total of 8 deaths, which represents a mortality rate of $0.39 \%$ in the population of 2020 calves. There were 3 cases from farms in Bouake, 2 cases from farms in Abidjan, and 3 cases from farms in Korhogo and Bondoukou.

\section{Analytic epidemiology}

Data from the survey point to various factors inherent to the management system which enable the incidence of calf diarrhea.

\section{Risk factors associated with calf diarrhea}

These factors can be categorized under calf environment, animal feeding, and hygiene management and vaccination.

\section{The calves}

There was no plan to evaluate the quality and quantity of colostrum consumed by the calves, and there was either insufficient control or a delayed intake of colostrum. Most farmers (95\%) practiced residual calf suckling. The cows were milked once a day in the morning, and the calf was allowed to suckle the residual milk for 20-30 minutes. The amount of milk available to the calf was therefore determined by the quantity of milk that remained after milking. The cows were milked on the 3rd day after calving. Most calves on the farms drunk polluted water and had restricted access to clean water. They did not receive care. 


\section{Calf environment \\ Calf housing and Herd size}

Based on the survey, most of the calves $(90 \%)$ were not housed separately in facilities for calves, but they were "sheltered" by the cows. The animals were kept in close confinement in the parks, and there was a lack of calf segregation based on their calving date. As for calf management, none of the interviewed herdsmen had calving facilities.

A notable increase in population density commonly results in an increase in the incidence of calf diarrhea (Table 2). Herd size was the most important risk factor for neonatal calf diarrhea. The rate of incidence of calf diarrhea was significantly higher in larger herd sizes. The difference between the proportions of diarrheic calves based on herd size was statistically significant $(p=0.029<0.05)$. Herd size had a significant association with the occurrence of diarrhea.

\section{Other animals}

The results of this study revealed the presence of other animal species roaming around in the calves' environment. These species included pets, humans, insects, rodents, and birds.

\section{Animal feeding}

The livestock almost exclusively grazed on natural pasture. The results of the study indicated that, with the exception of park troughs and natural drinking troughs such as lakes, rivers, brooks, and other sources, the livestock often drank stagnant and muddy water: a dreadful source of infestation.

\section{Hygiene management and vaccination}

The facilities and animals lacked cleanliness and hygiene. In all of the herds surveyed, the animals were kept on farms with mud floors, none of which were effectively disinfected. After birth, the calves were not separated from each other in the space to prevent contact and contamination from the feces and urine of other calves. They were directly exposed to contaminated environments. There was a concentration of fecal matter and a high moisture content. Finally, the maintenance for all the feeding and milking equipment did not adhere to strict hygiene practices. There was no compliance with the cleaning and disinfection procedures essential to covering all infectious agents of concern.

Animals purchased (or traded) from market sources were introduced to the herd without a quarantine plan. There was no place to isolate sick calves. Comfort and hygiene measures were unsatisfactory. The facilities were not disinfected, and the calves were not given adequate space. The farms in the study had not vaccinated the cows against diarrhea. The caregivers' (herdsmen) activities were not closely supervised by the owners.

\section{DISCUSSION}

\section{Descriptive epidemiology}

This study examined the incidence of calf diarrhea in order to identify the importance and magnitude of the factors that put calves at risk on these farms in Ivory Coast. The results of this investigation showed that calf diarrhea was the most common calf disease reported by the farmers, thereby confirming other reports (LEMMA et al. 2001, WUDU et al. 2008).

More than $90 \%$ of the herdsmen surveyed in the study were illiterate. This is incomparable to the estimation made by ADMASU et al. (2016), who estimated that $50 \%$ of the herdsmen in Ethiopia were illiterate. Most of the herds (88.26\%) surveyed in this study had cases of diarrhea. This result is somewhat similar to those found in other studies in France where $81 \%$ of the herds had reported cases of diarrhea (BENDALI et al. 1999).

The incidence rate of calf diarrhea (17.17\%) observed in the study was much lower than those found in other studies: 29\%, 63.3\%, and 69.34\% in Ethiopia (FEREDE et al. 2014, ASEFA \& ASHENAFI 2016, DAGNE et al. 2018) and 6\% in England (ORTIZ-PELAEZ et al. 2008). Our findings were higher than reports from other countries: $10 \%$ in Ethiopia (ALEMAYEHU et al. 2013), 14.15\% in Nigeria (SUNDAY et al. 2016), and $14.6 \%$ in France (BENDALI et al. 1999).

There may be several reasons for the relatively small mortality rate of $0.39 \%$ in our study, compared to the findings by WINDEYER et al. (2012) (3.5\%), GEBREMEDIHIN (2014) (11.6\%), TSEGAW (2016) (20.9\%), and MULUKEN et al. (2017) (4.68\%). The mortality rate remained low on the farms, while $88.26 \%$ of the cattle farms in the regions in question had cases of neonatal calf diarrhea. There were also some reported cases of severe dehydration, morbidity, and weight loss of diarrheic calves on many of the farms surveyed (95\%). This may be explained by the extensive system adopted in Ivory Coast, where calves are not regularly confined and are more resistant. This management system in third world countries could significantly reduce the burden of pathogenic microorganisms in the contamination cycle. The animal's 
inability to choose what to eat could also be a contributing factor. When considering biocontainment, it is critical to realize that the size of the inoculum or the pathogen load (exposure dose) is a major factor in determining the degree of clinical disease and the rapidity of its onset (BARRINGTON et al. 2002). This is supported by LORENZ et al. (2011) in Ireland and SUNDAY et al. (2016) in Nigeria, who argued that an extensive management system had a low percentage of positivity to the disease while an intensive management system had a high percentage of positivity.

In this study, age had a significant association with diarrhea in all age groups. The highest risk of diarrhea was observed in the first (1) month of life. Calves in the age groups of one to two months and two to three months were the least susceptible. This corroborates other findings that the incidence of disease is the highest during the first weeks of life (BARTELS et al. 2010, SUNDAY et al. 2016, ABEBAW et al. 2018).

Male calves tended to get more sick than female calves. The reason for this may be that farmers watched female calves more carefully due to their economic importance. To support these findings, SWAI et al. (2010) in Tanzania, BANGAR et al. (2013) in India, and MELLADO et al. (2014) in Mexico reported that diarrhea occurred in male calves more often than in female calves. These results did not align with those obtained by ASEFA \& ASHENAFI (2016) in Ethiopia.

Our survey considered the possibility of a seasonal effect. The incidence rate of calf diarrhea was higher in the rainy season than in the dry season. The increased incidence rate during the rainy season was closely related to the cold, wet, windy weather. It was also higher in the calving season. There are several reasons for these facts. Healthy adult cattle may be carriers and periodically excrete the microorganisms in feces. Excretion may increase around calving season. This can lead to contaminated calving areas and to infection of the udder in the cows. Other sources of infection include the feces of both healthy and diarrheic calves, which contain large numbers of organisms early in the course of infection. Diarrheic calves may be the result of insufficient attention and care. The seasonal impact has been reported by many authors (BENDALI et al. 1999, WUDU et al. 2008, FOSTER \& SMITH 2009).

\section{Analytic epidemiology}

As reported, most farmers (95\%) practiced residual calf suckling. This was associated with a higher risk of occurrence of calf diarrhea. Failure of passive transfer of maternal immunity through colostrum intake is a major risk factor for the development of neonatal diarrhea (LARSON et al. 2004, ABEBAW et al. 2018). Several studies have previously shown that a sufficient intake of colostrum soon after birth prevents the onset of calf diarrhea in the first 21 days of life by $31 \%$. Colostrum provides the necessary components of immunity at a time when the calf is not immunoactive but is exposed to pathogens in its environment (BARRINGTON et al. 2002, NIGUSSIE 2019). A previous study demonstrated that the beneficial effect of colostrum is observed in the calf's increased food consumption and weight gain. Small weight gains seen in the second week of calves on the irregular colostral diet (with milking) coincided with pathological manifestations (QUIGLEY et al. 1994, VASSEUR et al. 2009, KOUTINHOUIN et al. 2010).

On most of the farms, the calves $(90 \%)$ were housed together with the cows, which increased the calves' exposure to pathogens disseminated by asymptomatic adults. Livestock housing conditions greatly affects health and productivity (MEAS et al. 2002). Several studies have revealed that calves housed in individual calf hutches shed fewer enteric pathogens in their feces than calves left with their mothers in an enclosed space (GULLIKSEN et al. 2009, ADMASU et al. 2016, ABEBAW et al. 2018).

Based on the survey, the incidence rate of calf diarrhea was significantly higher in larger herd sizes. Herd size in itself does not have a biological effect on calf health; rather, it may be an indicator of other factors, such as the available time to observe and take care of the calves. This is supported by ABEBAW et al. 2018, GEBREMEDIHIN (2014), and YIBRAH \& TSEGA (2017). Another possible reason may be a "spread-out calving season," which is related to reproductive management. This practice is believed to be the cause of intercalving contaminations. These observations are consistent with the findings of many authors (ESUBALEW \& DEBEB 2017, ABEBAW et al. 2018, NIGUSSIE 2019).

Many of the potential risk factors lie in the management system. Livestock housing conditions greatly affect health and productivity. In all of the herds surveyed, the animals were kept on farms with mud floors. This uncomfortable environment for calves promotes the development of pathogens. One explanation may be the difficulty in cleaning and drying mud floors. None of the farms were effectively disinfected. As reported by MEAS et al. (2002), LINDSAY (2012), and DAGNE et al. (2018) muddy, wet conditions have proven to be the source of increased occurrences of calf diarrhea as the pathogens can grow rapidly.

Our study indicates that appropriate cleaning and disinfection procedures are critical to breaking fecaloral transmission cycles of enteric agents that contaminate housing, feeding, or livestock equipment. Other studies (SHIFERAW et al. 2002) also registered a significant association between a higher risk of occurrence 
of diarrhea and poor hygiene in the livestock area.

Based on the survey, the introduction of animals into the herd was a risk factor for calf diarrhea. Animals that have been purchased from or exchanged in sale yards are more likely to have been exposed to higher concentrations and a wider variety of pathogens compared to single-source or grazing animals. This is maintained by WEAVER et al. (2000) and BARRINGTON et al. (2002), who reported that these purchased animals often introduced new strains of infectious agents that then spread through the herd in an outbreak, which made the situation considerably worse.

Most farmers practiced residual calf suckling, a practice which is associated with a high risk of incidence of calf diarrhea, according to several authors. An unlimited intake of colostrum improves the calves' growth performance, reduces their perinatal mortality and morbidity rates, and increases breeding productivity. Colostral immunity is most important for newborn calves as their own immunity is weak (KOUTINHOUIN et al. 2010, ABEBAW et al. 2018).

Mechanical or biological vectors of enteric infectious agents may increase the incidence of diarrhea in the calf environment, as stated by BARRINGTON et al. (2002). Several authors have evidenced that vaccinated mothers protect calves against enteric pathogens. There was lower calf mortality when the caregivers' (herdsmen) activities were closely supervised by the owners (HECKERT et al. 2005, WUDU et al. 2008).

\section{CONCLUSION}

The results of this study made it possible to estimate the incidences of neonatal calf diarrhea and to identify the riskiest practices within the beef sector in Ivory Coast. Factors such as colostrum intake, the calf's age and sex, calf housing, seasonal variation, the calving period, environment conditions, the ignorance of herdsmen, and the management system were found to be the most important indicators of calf health problems. In an extensive system, the breeder should consider the cost/production ratio in using a potential vaccine against neonatal calf diarrhea. However, it is imperative to plan the administration of a vaccine against neonatal calf diarrhea for cattle beeding in an intensive system. The following recommendations seek to reduce the risk of calf diarrhea and promote good health:

Educate farm owners on the risks of calf diarrhea and the implementation of better calf management practices.

Vaccinate cows in order to control calf gastroenteritis. Vaccinate the cows and pregnant heifers with any necessary vaccines for calf diarrhea vaccines well before calving season.

Treat calf diarrhea with rehydration thorough the use of oral and intravenous electrolytes.

Control colostrum intake in the first days of calving.

A quarantine period of 21 days should be adequate to make a clinical assessment of animals.

\section{ACKNOWLEDGEMENTS}

The authors gratefully thank PADECI (livestock development support project in Ivory Coast).

\section{REFERENCES}

ABEBE $R$ et al. 2008. Epidemiology of Eimeria infections in calves in Addis Ababa and Around Addis Ababa Dairy Farms, Ethiopia. International Journals Applied Research Veterinary Medicin 6: 24-30.

ABEBAW R et al. 2018. A Review On The Importance Of Calf Diarrhea In Dairy Production System: Ethiopian Perspective. Journal of American Science 14: 71-83.

ACHA SJ et al. 2004. Studies on calf diarrhea and Prevalence of bacterial pathogens. Acta Veterinaria Scandinavica 45: 27-36.

ADMASU M T et al. 2016. Major Management and Health Problems of Calves in Smallholder Dairy Farms in Selected Areas of Dugda Bora, Arsi Negelle, Shashemene and Kofelle Woredas. Journal of Veterinary Science and Technology 7: 351-359.

ALEMAYEHU R et al. 2013. Cryptosporidium in calves, lambs and kids haramaya, eastern Ethiopia. Ethiopian Veterinary Journals 17: 81-94.

ASEFA AA \& ASHENAFI K. 2016. Dairy calf morbidity and mortality and associated risk factors in Sodo town and its suburbs, Wolaita zone, Ethiopia. Solavak Journal of Animal Science 49: 44-56.

BANGAR $Y$ et al. 2013. Analysis of morbidity and mortality rate in cattle in village areas of Pune division in the Maharashtra State. Veterinary World 6: 512-515.

BARRINGTON GM et al. 2002. Biosecurity for neonatal gastrointestinal diseases. Veterinary Clinics of North America: Food Animal Practice 18: 7-34.

BARTELS CM et al. 2010. Prevalence, prediction and risk factors of Enteropathogens in normal and no normal faces of young dairy calves. Preventive Veterinary Medicine 93: 162-169. 
BENDALI F et al. 1999. Pattern of diarrhoea in newborn beef calves in south-west France. Veterinary Research Biomed Central 30: 61-74.

DAGNE K et al. 2018. Occurrences of Dairy Calf Mortality and Morbidity and the Associated Risk Factors in Sululta and its Environs, Central Ethiopia. Journal of Veterinary Science \& Animal Husbandry 6: 503-514.

ESUBALEW S \& DEBEB D. 2017. Reterospective Study on Calf Mortality in Dairy Farms in Gondar Town. International Journal of Advanced Research and Publications 1: 48-54.

FEREDE Y et al. 2014. Pre-Weaning Morbidity and Mortality of Crossbred Calves in Bahir Dar Zuria and Gozamen Districts of Amhara Region, Northwest Ethiopia. Open Access Library Journal 1: 1-8.

FOSTER DM \& SMITH GW. 2009. Pathophysiology of diarrhea in calves. Veterinary Clinic of North America Food Animal Practice 25: 13-36.

GEBREMEDIHIN RE. 2014. Major Causes of Calf Mortality in Intensive Dairy Farms, Central Ethiopia. International Journal of Livestock Research 4: 9-16.

GULLIKSEN SM et al. 2009. Enteropathogens and risk factors for diarrhea in Norwegian dairy calves. Journal of Dairy Science 92: 5057-5066.

HECKERT HP et al. 2005. Effects of maternal immunization of cows a field study. Der Praktische Tierarzt 86: 500.

KOUTINHOUIN BG et al. 2010. Influence of precocious milking of cows on the growth and the health of calves in traditional breeding in the suburban zone of Natitingou (Benin). Livestock Research for Rural Development 22 : 1-8.

LARSON RL et al. 2004. Management strategies to decrease calf death losses in beef herds. Journal of the American Veterinary Medical Association 224: 42-48.

LEMMA M et al. 2001. Clinically manifested major health problems of crossbred dairy herds in urban and periurban production systems in the central highlands of Ethiopia. Tropical Animal Health and Production 33: 85-93.

LINDSAY L. 2012. Morbidity and mortality rates based on stress levels in dairy calves. Senior Project (Bachelor of Science). San Luis Obispo: California Polytechnic State University. 82p.

LORENZ I et al. 2011. Calf health from birth to weaning. I. General aspects of disease prevention. Irish Veterinary Journal 64: 2-9.

MAES P et al. 2010. Étiologie des diarrhées néonatales et transfert colostral chez le veau: enquête dans la creuse. Thèse. (Doctorat vétérinaire). Maisons-Alfort : École Nationale Vétérinaire d'Alfort. 102p.

MEAS S et al. 2002. Vertical transmission of bovine leukemia virus and bovine immunodeficiency virus in dairy cattle herds. Veterinary Microbiology 84: 275-282.

MELLADO $\mathrm{M}$ et al. 2014. Factors associated with neonatal dairy calf mortality in a hot-arid environment. Livestock Science 159: 149-155.

MULUKEN T et al. 2017. Major Causes and Risk Factors Associated with Calf Mortality in Small Scale Dairy Farms in Gondar Town, Ethiopia. Academic Journal of Animal Diseases 6: 67-74.

NIGUSSIE T. 2019. Review on the major causes and associated risk factors of calf morbidity and mortality in dairy farms of Ethiopia. Journal of Dairy, Veterinary \& Animal Research 8: 83-92.

ORTIZ-PELAEZ A et al. 2008. Calf mortality as a welfare indicator on British cattle farms. Veterinary Journal 176: 177181.

ØSTERAS $\mathrm{O}$ et al. 2007. Perinatal death in production animals in the Nordic countries - incidence and costs. Acta Veterinaria Scandinavica 49: 1-14.

QUIGLEY JD et al. 1994. Effects of housing and colostrum feeding on the prevalence of selected infectious organisms in feces of Jersey calves. Journal of Dairy Science 77: 3124-3131.

RAVARY B et al. 2006. Néonatologie du veau. Du Point Vétérinaire 10: 90-95.

SHIFERAW $Y$ et al. 2002. Dairy husbandry and health management at Holleta. In: Proceeding of the 16th conference of the Ethiopian Veterinary Association. Addis Ababa 5: 103-119.

SUNDAY CO et al. 2016. Calf Diarrhea: Epidemiological Prevalence and Bacterial Load in Oyo and Ogun States, Nigeria. Alexandria Journal of Veterinary Sciences 51: 90-96.

SWAI ES et al. 2010. Risk factors for smallholder dairy cattle mortality in Tanzania. Journal of the South African Veterinary Association 81: 241-246.

THICKET B et al. 2003. Calf rearing. 2.ed. Great Britain: Biddies Clean Ltd. 1252p.

TSEGAW F. 2016. Assessment of Young Stock Mortality in Major Livestock Production Systems of Ethiopia. United States Agency for International Development 3: 5-41.

VASSEUR E et al. 2009. Does a calf's motivation to ingest colostrum depend on time since birth, calf vigor, or provision of heat? Journal of Dairy Science 92: 3915-3921.

WEAVER DM et al. 2000. Passive transfer of colostral immunoglobulins in calves. Journal of Veterinary Internal Medicine 14: 69-77.

WINDEYER MC et al. 2012. The effects of viral vaccination of dairy heifer calves on the incidence of respiratory disease, mortality, and growth. Journal of Dairy Science 95: 6731-6739.

WUDU T et al. 2008. Calf morbidity and mortality in smallholder dairy farms in Ada'a Liben district of Oromia, Ethiopia. Tropical Animal Health and Production volume 40: 369-376.

YIBRAH T \& TSEGA B 2017. Cross-Sectional Study on Calf Health and Management Problems on Small Scale Dairy Farms of Sidama and Gedio Zones, Southern Ethiopia. Journal of Veterinary Science and Technology 8: 437-445. 